\title{
IS-31
}

\section{歯科用エアタービンハンドピースによる切削音の音響心理評価 Psychoacoustic evaluation of noise emitted by dental air-turbine handpieces}

\author{
○山田 朋美*，林 美加子*，桑野 園子* \\ Tomomi YAMADA*, Mikako HAYASHI*, Sonoko KUWANO* \\ * 大阪大学 Osaka University
}

Key Words：歯科ドリル，騒音，音響心理，タービン，音響物理量

\section{要旨}

緒言 : キーンという音を伴う歯科用エアタービンハンドピースは歯を削る代表的な歯科ドリルである(図 1 ). ヘッド部には小型タービンが内蔵され，圧縮空気により駆動するタービンとともに、チャック機構により保持さ れた切削用ポイントが高速回転（300,000 〜 400,000 rpm/min）することでエナメル質や金属冠を削ることが可能 となる．優れた器具であるが歯科治療時に発生する音は多くの患者に不安や不快な感情を引き起こす ${ }^{(1)}$. 我々は, より快適な音環境を提供するための新たな歯科ドリル開発を目指している. そのため,歯科ドリル音の不快といっ た主観的な感覚量と音の物理量との関係を明らかにする目的で音響心理評価実験を行った.

方法 : 大阪大学歯学部附属病院において, 歯科ドリル音 (空転音および人工歯を削っている切削音) を収録し, 音圧レベル等が異なる 40 の音刺激（各 5 秒）を準備した。被験者には，防音室内でこれらの音刺激を聴取し，SD 法 ${ }^{(2)}$ により，15 の形容詞対（大きい一小さい，鋭い一鈍い 等）に対して 7 段階で評価するよう求めた. 音刺激

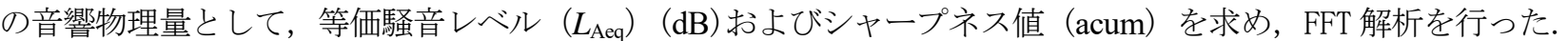

結果と考察 : FFT 解析の結果, ドリル音には複数の突出した特徵周波数を含む豊富な周波数成分が $20 \mathrm{kHz}$ に至 る幅広い帯域に認められた．因子分析の結果，歯科ドリル音の印象は「迫力のある」「不快・金属的な」といった

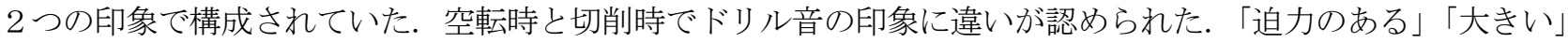

「騒々しい」といった印象は等価騒音レベルと強い相関が認められた．また，「金属的な」「とげとげしい」とい った印象はシャープネス值との相関が認められた. 桑野らは, 等価騒音レベルとシャープネス值を用いた Comfort Index $\quad\left(C I=L_{\text {Aeq }} 10+\right.$ sharpness $)$ という指標を報告している. 歯科タービン音における $C I$ と不快な」「好ましく ない」「嫌な」といった印象との関係を調べたところ高い相関が得られた．CI と「快い一不快な」との関係を示 す（図 2）。歯科ドリル音の不快感は快適指標 Comfort Index（CI=L $L_{\mathrm{Aeq}} / 10+$ sharpness）により予測できる.

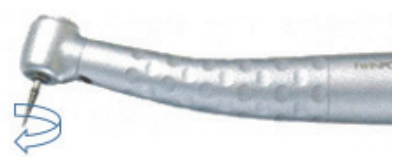

Figure 1 A dental air turbine handpiece with a diamond point

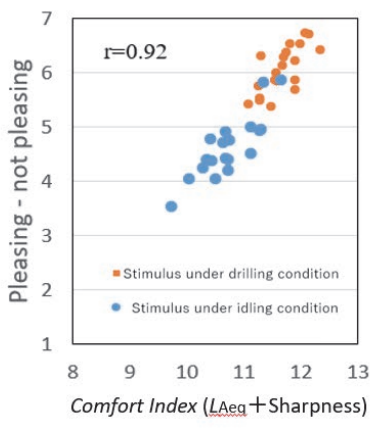

Figure 2 Relationship between $C I$ and the adjective scale values for "pleasing-not pleasing" of the all sound stimuli.

(1) Yamada T, Kuwano S, Ebisu S., "A questionnaire survey on the effect of the sound of dental drills on the feeling of patients in dental clinics",. Acoust Sci Tech, Vol. 27 (2006), pp. 305-308.

（2）難波 精一郎, 桑野 園子, 音の評価のための心理学的測定法 コロナ社, 東京 (1998). 